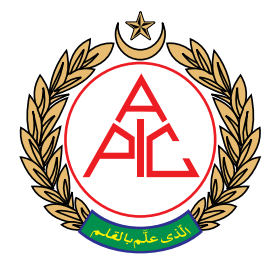

${ }^{1}$ Department of Physical Medicine \& Rehabilitation, Faculty of Medicine, Universitas Airlangga, Surabaya, (Indonesia) Department of Pharmacology, Faculty of Medicine, Universitas A̧irlangga, Surabaya, (Indonesia) Department of Pathologic Anatomy, Faculty of Medicine, Universitas Airlangga, Surabaya, (Indonesia)

Department of Neurology, Faculty of Medicine, Universitas Airlangga, Surabaya, (Indonesia) Correspondence:

Dr Hanik Badriyah Hidayati, Department of Neurology,

Faculty of Medicine, Universitas Airlangga -Soetomo Academic Medical Hospital, Mayjen Prof. Dr. Moestopo Str. 47, Surabaya - 60131, (Indonesia); Phone: (+62) 82131035699; E-mail: hanikhidayati@yahoo.com Received: 6 February 2019; Reviewed: 16 February 2019, 2 August 2019;

Revised: 9 September 2019;

Accepted: 15 September 2019

\section{Wet cupping therapy improves mu opioid receptor expression and pain threshold in animal models of inflammation}

\author{
Imam Subadi ${ }^{1}$, Martha Kurnia Kusumawardani ${ }^{1}$, \\ Mohammad Fathul Qorib ${ }^{2}$, Imam Susilo ${ }^{3}$, Hanik Badriyah Hidayati ${ }^{4}$
}

\begin{abstract}
Background \& Objectives: Treatment of chronic pain using NSAIDs, steroids, opioids, and herbs has been associated with many complications with the long-term use. Wet cupping therapy (WCT) has been used to reduce pain, by triggering mu opioid receptor expression. We conducted this study to compare the effectiveness between WCT with oral opioids for pain management.

Methodology: It was an experimental study with randomized control group post-test only design. Thirty two male white rats of strain Wistar were divided into four groups: (1) Group-NC; mice in this group were given nothing as a negative control group, (2) Group-CFA; group that was given Complete Freund's Adjuvant (CFA) only as a positive control group, (3) Group-WCT; mice were given CFA and WCT, and (4) Group-O was given CFA and oral opioids. The measured variables were pain threshold value and mu opioid receptors. Statistical analysis was done us(ing SPSS software (version 22.0, Chicago, IL).
\end{abstract}

Results: The results showed no significant differences in the expression of $m u$ opioid receptors between Group-NC and Group-CFA ( $p=0.061$ ). There were significant differences in the expression of opioid receptors between Group-CFA and Group-WCT $(p<0.001)$, and also between WCT group and Group-O $(p=0.002)$. The differences of pain threshold value were only significant between Group-NC $(p=0,006)$ and GroupCFA $(p=0,013)$ with Group-O.

Conclusion: Wet cupping therapy triggers the expression of mu opioid receptors. Wet cupping therapy as effective in relieving pain as opioids.

Key words: Pain management; Oral opioids; Wet cupping therapy; Alternative therapy

Citation: Subadi I, Kusumawardani MK, Qorib MF, Susilo I, Hidayati HB. Wet cupping therapy improves mu opioid receptor expression and pain threshold in animal models of inflammation. Anaesth pain \& intensive care 2019;23(4):348-352.

DOI: https://doi.org/10.35975/apic.v23i4.1166

\section{INTRODUCTION}

Prevalence of chronic pain continues to increase, reaching $41 \%$ in developing countries. ${ }^{1}$ Chronic pain causes disruption of daily living activities, such as sleep disorders, sports activities, housework, attending social activities, sexual life, and independence of lifestyle. Treatment of chronic pain includes NSAIDs (nonsteroidal anti-inflammatory drugs), steroids, opioids, and herbs. NSAIDs are used as the first choice of pain management, but often cause gastric bleeding in long-term use. Whereas, opioid administration causes addiction, tolerance, and the most feared side effect of respiratory depression.

Recently, wet cupping therapy (WCT) has been used to reduce pain. Previous studies showed that WCT effectively reduced lower back pain ${ }_{8}^{5}$, headache ${ }^{6}$, carpal tunnel syndrome, and neck pain . Study by Subadi (2017) showed that WCT triggered $\beta$-endorphin 
expression. ${ }^{9}$ The main $\beta$-endorphin receptor is opioid $m u$ receptor. ${ }^{10}$ The bond between $\beta$ - endorphins with these receptors will reduce cAMP and inhibit $\mathrm{Ca}^{++}$ / $\mathrm{Na}^{+}$entry, as a result, glutamate release will be inhibited. ${ }^{11}$ Wrigley et al. reported that opioid $m u$ receptors inhibit glutamatergic synapse transmission in the dorsal horn of the spinal cord. ${ }^{12}$ Glutamate is a neurotransmitter of pain impulses, it is thought that the reduction of pain in WCT occurs due to $\beta$-endorphin expression.

This study aimed to compare effectiveness of WCT with oral opioids by assessing the number of nerve cells in lamina 1 dorsal horns of the spinal cord that express opioid mu receptors and pain threshold values. Opioid mu receptors expression is hypothesized higher in wet cupping than oral opioids, consequently it can be used as a safer alternative for pain management.

\section{METHODOLOGY}

This was a randomized control group post test only design study. The study protocol was approved by the Ethics Committee of the Faculty of Veterinary Medicine, Universitas Airlangga, Surabaya, Indonesia (Ethics \# 2KE. 110.07.2018). Thirty two 3 month old healthy male Wistar rats were included. Sick and lazy rats were excluded. The rats were randomized into 4 groups:

1. Group-NC: mice were given nothing as a negative control group,

2. Group-CFA: group that was given Complete Freund's Adjuvant (CFA) (Sigma-Aldrich, Saint Louis, Missouri, USA) only; a positive control group,

3. Group-WCT; group was given CFA and WCT, and

4. Group-O: group that was given CFA and oral opioids.

\section{Animal Experiment:}

The rats were housed in cages (4-5 per cage) for 7 days under a 12:12 hour light / dark cycle (lights off at 19.30 hours) and at constant temperature $\left(24^{\circ} \mathrm{C}\right)$. Food (Pelet BR 511, Comfeed, Indonesia) and tap water was available $a d$ libitum.

At the eighth day, rats in the Group-CFA, Group-WCT, and Group-O were induced using CFA $100 \mu \mathrm{L}(1 \mathrm{mg} /$ $\mathrm{ml})$ on the ventral surface of the right hind paw centered in the footpad. ${ }^{13} \mathrm{CFA}$ is injected in animal models to induce inflammation, in order to assess the production of inflammatory mediators. At $48 \mathrm{~h}$ after CFA induction, Group-O rats were given codeine (Kimia Farma, Indonesia), orally with a dose of $5 \mathrm{mg} / \mathrm{Kg}$. Meanwhile, WCT was carried out by performing 10 punctures with lancets, followed by skin extraction with $-200 \mathrm{mmHg}$ of a negative pressure for $5 \mathrm{~min}$, on the right and left back with a diameter of $2 \mathrm{~cm}$

cup. ${ }^{5,7}$ Pain threshold values were calculated by recording the time between the placement of mice on the hot plate (Hot plate, UGO BASILE, Italy) at a temperature of $51^{\circ} \mathrm{C}$, until the mice lick the soles of their feet or jump within a $30 \mathrm{sec}$ cutoff time. One measurement was taken using a stopwatch for each animal to obtain paw withdrawal latency. ${ }^{14}$

\section{Immunohistochemistry Assay}

The effects of wet cupping and opioid are presented in Figure 1. The expression of mu opioid receptor positive cells were tested by immunohistochemistry using antibody monoclonal anti mu opioid receptor purchased from Abcam (Cambridge, USA). The positive cells for mu opioid receptor expressions were cells which stained brown on membranes of nerve cell in the dorsal horn of the spinal cord. It was counted using a light microscope (Olympus CX 2, New York, USA) with 1000 times magnification, at twenty different viewpoints in lamina I area. The results of each calculation were written on a worksheet, and the mean value of each field of view was calculated.

Data analysis: Collected data were analyzed using SPSS software (Version 22.0, Chicago, IL), to assess normality of the data to carry out hypothesis testing using the appropriate method choices. Independent $\mathrm{T}$ Test was used to compare pain threshold between Group-WCT and control group. Mann-Whitney U Test was used to compare expression of mu opioid receptors and pain threshold between Group-WCT and Group-O.

\section{RESULTS}

\section{Expression of Mu Opioid Receptor}

The expression of mu opioid receptors according to immunohistochemistry demonstrated positive cells

Table 1: Pain threshold value between groups

\begin{tabular}{l|l|l|l|l|c}
\multirow{2}{*}{\multicolumn{1}{c|}{ Groups }} & \multicolumn{4}{c|}{ Pain threshold value (s) } & \multirow{2}{*}{ p value* } \\
\cline { 2 - 5 } Group-NC & \multicolumn{1}{|c|}{$\mathbf{X}$} & \multicolumn{1}{|c|}{ SD } & \multicolumn{1}{c}{ Min } & Max & \\
\hline Group-CF & 18.51 & 1.95 & 13.70 & 30.00 & $\mathrm{p}=0.006(\mathrm{a})$ \\
\hline Group-WCT & 21.48 & 1.68 & 13.0 & 27.60 & $\mathrm{p}=0.013(\mathrm{~b})$ \\
\hline Group-0 & 23.23 & 2.07 & 15.20 & 30.00 & $\mathrm{p}=0.057(\mathrm{c})$ \\
\hline
\end{tabular}




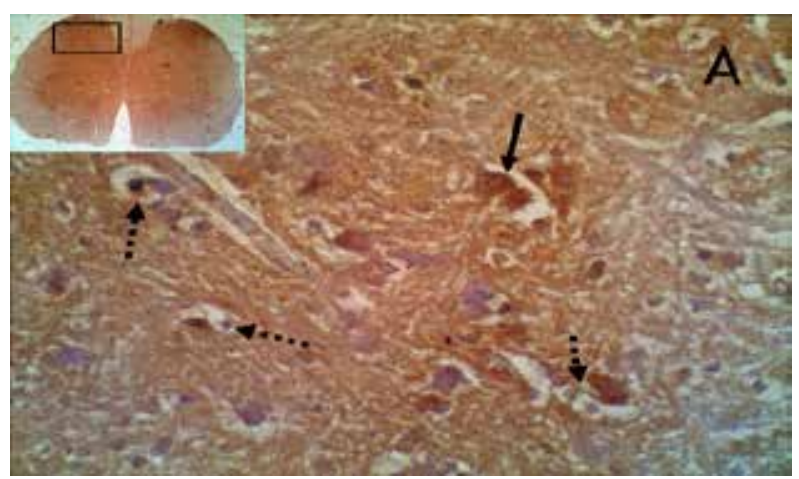

Figure 1A: Expression of mu opioid receptor in the Group-NC

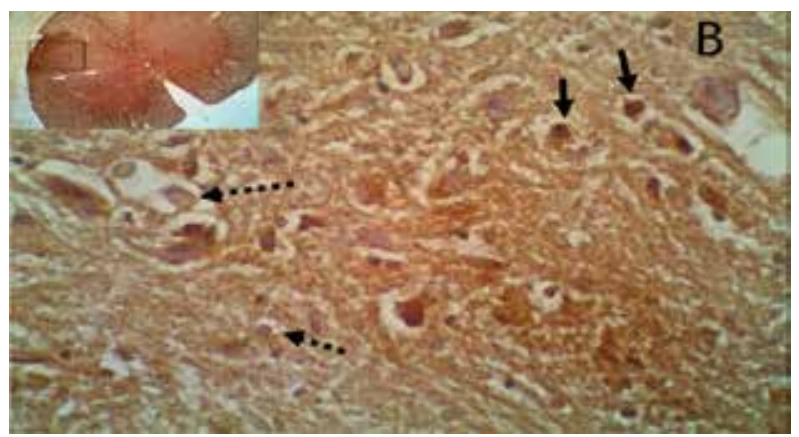

Figure 1B: Expression of mu opioid receptor in the Group-CFA

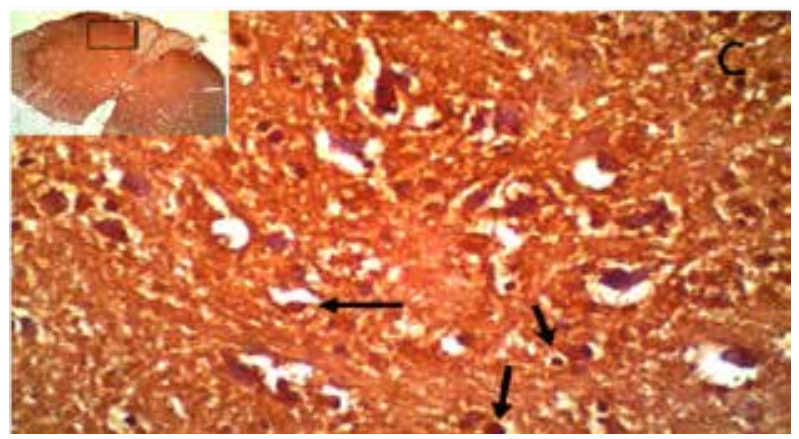

Figure 1C: Expression of mu opioid receptor in the Group-WCT

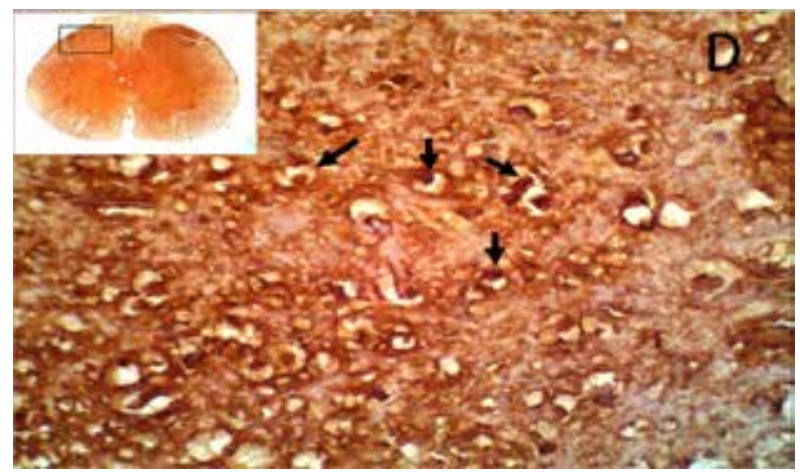

Figure 1D: Expression of mu opioid receptor in the oral Group-O (posterior lamina I of the spinal cord), which were brown in color, more in Group-WCT and Group-O than in the Group-NC and Group-CFAs (Figures 1A to $1 \mathrm{D})$.

Figure 1: Immunohistochemistry showing the distribution of mu opioid receptors in rat spinal cord (light microscope, magnification 1000). A- Expression of $\mathrm{mu}$ opioid receptors in the Group-NC, showing a small number. B-Expression of mu opioid receptor in the Group-CFA also showing asmallnumber. C-Expression ofmuopioidreceptorsintheGroup-WCT,D- showing a nelevated number in Group-O.

Arrows show positive reaction, dotted arrows show negative reaction.

Counting the number of the positive cells in the lamina I of spinal cord revealed a significant higher number of cells that expressed mu opioid receptors $(\mathrm{p}<0.001)$ in the Group-O than in the Group-WCT. Significant higher number of cells that expressed mu opioid receptors also showed in Group-WCT than in the negative and Group-CFAs $(\mathrm{p}<0.001)$ (Figure 2).

The pain threshold test was done $24 \mathrm{~h}$ after WCT, 1 hour after oral opioid and $72 \mathrm{~h}$ after the CFA injection in the control groups. There were no significant differences in the pain threshold value between Group-NC and Group-CFA ( $\mathrm{p}=0.254)$; Group-CFA and Group-WCT ( $\mathrm{p}=0.499)$; also Group-WCT and Group-O (p = 0.057) (Table 1).

\section{DISCUSSION}

We have all seen various Olympic athletes with distinct 'circles' on their body as a result of cupping therapy. We must explore how it works. Cupping therapy has been defined by the World Health Organization (WHO) as a therapeutic method using suction created by a vacuum. ${ }^{15}$ There are two types of cupping therapy, dry cupping and WCT. Dry cupping pulls the skin into the cup without scarification, while in wet cupping the skin is lacerated so that blood is drawn into the cup. Cupping therapy is reported to treat a variety of diseases due to the effects of multiple types of stimulation. Cao and associates suggested that cupping therapy appears to be effective for various medical conditions, in particular herpes zoster and associated pain and acne, facial paralysis, and cervical spondylosis. 16

The exact mechanism of cupping therapy to reduce pain until now is unclear. The most frequently discussed mechanisms are negative pressure effects that cause increased blood circulation, immunity, pain threshold, anaerobic metabolism, change the biomechanics of the skin, and reduce inflammation. Immunomodulation theory states that changes in the micro-environment by skin stimulation can alter biological signals and activate the neuroendocrine 
immune system. The theory of Shaban and Rarvalia states that stress on the skin due to negative pressure causes mechanical and physiological signals resulting in gene expression. ${ }^{16}$ Experimental animal studies reported the expression of heat shock protein (HSP 70) and $\beta$-endorphins as a possible mechanism for reducing pain after cupping therapy.

In this study, the expression of opioids $m u$ receptors in the two control groups that did not significantly differ, showed that administration of CFA induction could not increase the expression of opioid $m u$ receptor. Acute sterile inflammatory induction using CFA only slightly increases the expression of mu receptors, compared to Group-NC. This increase can be caused by a pain modulation process at post synapse level in dorsal horn. Results of this study indicate that wet cupping and opioid therapy can increase the expression of opioid $m u$ receptors, and confirm the previous research which states that cupping therapy has a similar mechanism of action with opioid analgesic drugs.

The difference of $m u$ receptor's expression in the Group-WCT and Group-O raises a new hypothesis that WCT is not strong enough to stimulate endorphin release; therefore, expression of $m u$ receptors is lower than in opioids group. Another possibility that can occur is WCT works as an analgesic through the central nervous system by stimulating the release of encephalin and/or dynorphin. These two endogenous opioids have less strong affinity for $m u$ receptor, as the consequence, expression of the receptor is lower than in codeine. The release of these two endogenous opioids will further activate the delta and kappa receptors. ${ }^{4}$ Both of these hypotheses will be targeted for further research.

Compared to positive controls $(21.48 \pm 1.68)$, WCT $(23.23 \pm 2.07)$ was not significant in reducing pain $(\mathrm{p}=0.499)$.

The administration of oral opioids $(28.01 \pm 1.44)$ was also not significant in reducing pain compared to WCT, nevertheless, it was significant compared to positive controls $(\mathrm{p}=0.13)$.

The mean of pain threshold value on GroupCFA showed differences even though it was not significant compared to Group-NC. It showed that in

experimental animals which have induced by acute inflammatory pain, pain modulation will occur and thermal pain stimulation will cause a slight increase in pain threshold value, compared with experimental animals that did not get previous pain induction.

\section{LIMITATIONS}

The results can be influenced by the differences of basic character of each experimental animal, which can be seen from the distribution of pain threshold values in each group. To avoid the result bias, a prepost test for the hotplate should be performed and the value to be compared between groups is a delta or changes in pain threshold values.

\section{CONCLUSION}

Wet cupping therapy can increase pain threshold in experimental animals. This can be seen from the results above, which showed differences in mean pain threshold, compared with control groups. Pain threshold mean of wet cupping therapy group was also not significantly different from the negative control group. This result can be interpreted that wet cupping therapy also has a potential antinociceptive effect as oral opioid. It had a better analgesic effect compared with control group, but the analgesic effect was not better than the opioid.

\section{ACKNOWLEDGMENTS}

The authors would like to express their deep gratitude 
wet cupping therapy and pain

to all of those who contributed to the success of this study.

Conflict of interest: Nil declared by the authors

Author' contribution: All authors took equal part in the conduct of study, data collection, manuscript preparation and editing.

\section{REFERENCES}

1. Croft P, Blyth FM \& Windt D. 2010. The global occurrence of chronic pain. In: Croft P, Blyth FM \& Windt D, eds, Chronic Pain Epidemiology. Oxford University Press, New York, p 9- 18.

2. Breivik $H$, Collett $B$, Ventafridda $V$, Cohen R \& Gallacher D. Survey of chronic pain in Europe: Prevalence, impact on daily life, and treatment. Eur J Pain 2006;10:287-333. [PubMed]

3. Gold MS \& Gebhart GF. 2010. Peripheral pain mechanisms and nociceptor sensitization. In (Fishman SM, Ballantyne JC \& Rathmell JP, eds). Bonica's Management of Pain. $4^{\text {th }}$ ed. Philadephia: Lippincott William \& Wilkins, p 24-34.

4. Katzung BG, Masters SB, Trevor AJ. 2012. Basic and Clinical Pharmacology, $12^{\text {th }}$ ed, p. $636-640$.

5. Farhadi K, Schwebel DC, Saeb M, Choubsaz M, Mohammadi R \& Ahmadi A. The effectiveness of wet-cupping for nonspecific low back pain in Iran. Complement Ther Med 2009;17:9-15. [PubMed]

6. Ahmadi A, Schwebel DC \& Rezaei M. The efficacy of wet-cupping in the treatment of tension and migraine headache. Am J Chin Med 2008;36:37-44 [PubMed]

7. Michalsen A, Bock S, Ludke R, Rampp T, Baeker M, Bachmann J, Langhorst
J, Musial F \& Dobos GJ. Effects of traditional cupping therapy in patients with carpal tunnel syndrome. J Pain 2009;10:1-8. [PubMed]

8. Arslan. M, Kutlu N, Tepe M, Yilmar NS, Ozdemin L \& Dane S. Dry cupping therapy decreases cellulite in women. Indian Journal of Traditional Knowledge 2015;14(3):p359-364 [Free full text]

9. Subadi I, Nugraha B, Laswati $\mathrm{H}$, Josomuljono $\mathrm{H}$. Pain relief with wet cupping therapy in rats is mediated by heat shock protein 70 and $\beta$-endorphin. Iran J Med Sci. 2017;41(4): [PubMed] [Free Full Text]

10. Pasternak GW, Pan YX. Mu Opioids and their receptors: evolution of a concept.

Pharmacol Rev. 2013;65: 1257-1317. [PubMed] [Free Full Text] DOI: 10.1124/pr.112.007138.

11. LesniakA, Lipkowski AW. Opioid peptides in peripheral pain control. Acta Neurobiol Exp.71:129-138. [PubMed]

12. Wrigley $P J$, Jeong $H J$, Vaughan $C W$. Dissociation of $\mu$-opioid inhibition of glutamatergic synaptic transmission in superficial dorsal horn. Mol Pain 2010;6:71. [PubMed] [Free Full Text] DOl: 10.1186/1744-8069-6-71.

13. Matson DJ, Broom DC, Carson SR, Baldassari J, Kehne J, Cortright
DN. Inflammation-induced reduction of spontaneous activity by adjuvant. J Pharmacol Exp Ther. 2007;320(1):194-201. [PubMed]

14. Paudel KR, Das BP, Rauniar GP, Sangraula H, Deo S, Bhattacharya SK. Antinociceptive effect of amitriptyline in mice of acute pain models. Indian J Exp Biol. 2007;45:529-531. [PubMed]

15. Dalton EL, Velasquez BJ. Cupping therapy: an alternative method of treating pain. Public Health Open J. 2017;2(2):59-63. [Free full text]DOI: 10.17140/ PH0J-2-122

16. Al-Bedah AMN, Elsubai IS, Qureshi NA, Aboushanab TS, Ali GIM, El-Olemy AT, et al. The medical perspective of cupping therapy: Effects and mechanism of action. $J$ Tradit Complement Med. 2018 Apr; 9(2): 90-97. [PubMed] [Free full text] DOI: 10.1016/i.jtcme.2018.03.003

17. Aboushanab TS, AISanad S. Cupping therapy: an overview from a modern medicine perspective. J Acupunct Meridian Stud. 2018;11(3):8387. [PubMed] DOI: 10.1016/j. jams.2018.02.001. 